\title{
Complex settlement and the landscape dynamic of the Iščica floodplain (Ljubljana Marshes, Slovenia)
}

\author{
Dimitrij Mlekuž ${ }^{1}$, Mihael Budja', Nives Ogrinc ${ }^{2}$ \\ 1 Department of Archaeology, Faculty of Arts, Ljubljana University, SI \\ dimitrij.mlekuz@guest.arnes.si, miha.budja@ff.uni-lj.si \\ 2 'Jozef Stefan' Institute, Department of Environmental Sciences, SI \\ nives.ogrinc@ijs.si
}

\begin{abstract}
This paper addresses the complex interactions between settlement patterns and landscape dynamics in the Išcica floodplain (the Ljubljana Marshes, Slovenia) during the early and middle Holocene. This complex interaction can be observed on many nested spatial and temporal levels. The paper examines landscape and settlement dynamics on the micro-regional scale by exploring settlement patterns and LiDAR (Light Detection and Ranging) imagery, and on the settlement scale by analysis and radiocarbon dating of stratigraphic sequences from the Maharski prekop site.

IZVLEČEK - Prisevek se ukvarja z prepoznavanjem kompleksnih interakcij med poselitvcenim vzorcem in dinamiko krajine v poplavni ravnici Išcice (Ljubljansko barje) $v$ zgodnjem in srednjem Holocenu. Kompleksne interakcije je moč opazovati v različnih prostorskih in časovnih merilih. V prispevku analiziramo poselitveno dinamiko na nivoju mikroregije skozi analize in korelacije poselitvenega vzorca in analize LiDAR posnetkov površja in na nivoju najdišča skozi analize in radikarbonsko datiranje stratigrafske sekvence na najdišč Maharski prekop.
\end{abstract}

KEY WORDS - Ljubljana Marshes; Neolithic and Eneolithic; landscape and settlement dynamics; digital surface model

\section{Introduction}

There have been two main episodes in the archaeological research of the Ljubljana Marshes. In the second half of the 19th century the 'pile dwellings' discovery was followed by extensive, but unsystematic documented excavations by Carl Deschmann in 1875 . The interpretative scenario that served the institutional promotion of national prehistoric archaeology was based on fashionable 'Kulturkriese' determinism and was visualised as a romantic landscape of pile dwellings situated on the lake margins and overshadowed by alpine peaks.

A hundred years later, intensive interdisciplinary fieldwork and excavations were undertaken in the Iščica floodplain (Bregant 1974a; 1974b; 1975). The excavations were focused on the Maharski prekop and Parte sites. While the results showed a complex settlement organisation and stratigraphic sequence, intensive landscape dynamics, a couple of early and middle Holocene palaeosoil formations (Stritar 1975. 143; Stritar and Lobnik 1985.67-70), a millenniumlong ${ }^{14} \mathrm{C}$ continuity of settlement, and evidence of agricultural activities in situ (cereal pollen) ( ̌́ ercelj 1975.121 and Tab. 2), interpretative postulates maintained the lake and the pile dwellings as archetypes determining Neolithic and Neolithic landscape and settlement patterns.

The interpretative focus shifted recently to pottery assemblages. Herman Parzinger and Anton Velušček suggest recognizing in the patterns of pottery decoration and morphological attributes a typo-chrono- 
logy of settlement structures, a sequencing of 'cultural' phases and the duration of settlement (Parzinger 1984; 1993; Velušček 2001; 2006). Dendrochronological research in the region resulted in several floating chronologies (Čufar et al. 1997; 1998; Velušček and Čufar 2001; Velušček et al. 2000); however, the results had little impact on archaeological interpretations.

The interpretation of the archaeological palimpsest at the Ljubljana Marshes was based on the study of fragments of data without reference to the wider context. We believe that this reductionist approach failed to acknowledge the complex landscape and settlement dynamic of the Marshes. Instead of the study of isolated fragments of data, we advocate a more holistic, landscape based approach, where fragments of the archaeological record can only be understood in relation to each other and to the landscape itself.

\section{Bringing the pieces together: settlement organi- sation and the dynamics of the Iščica floodplain}

The Iščica floodplain is one of the most intensively, however unsystematically, researched parts of the Ljubljana Marshes. Over 130 years of archaeological research has contributed a great amount of archaeological and environmental data which offer only a fragmentary image of settlement patterns (Fig. 2). We suggest that in order to approach the settlement dynamics of the Iščica floodplain, this vast corpus of available data should be put in context.

Almost 10000 vertical piles have been documented in the Iščica floodplain. This number is the result of large-scale digging activities and a number of testpits. In 1870 Carl Deschmann (Dragotin Dežman) excavated several large areas of approximately $12000 \mathrm{~m}^{2}$. Unfortunately, he provided scant field work documentation. ${ }^{1}$ There are, however, his manuscripts: reports and daily notes of digging and descriptions of finds available in the Slovenian National Museums. After Deschmann's digs only a few large-scale excavations were completed. Josip Korošc opened a subsurface window of $160 \mathrm{~m}^{2}$ at the Resnikov prekop in 1962 (Bregant 1964a; Korošec 1964).2 Tatjana Bregant excavated at Maharski prekop, where she opened up an area of $1220 \mathrm{~m}^{2}$ in the 1970s (Bregant 1974a; 1974b; 1975), and at Parte, where $640 \mathrm{~m}^{2}$ were excavated in the late 1970 s and early 1980s (Harej 1978; 1981; 1987). She introduced sophisticated excavation procedures and interdisciplinary approaches, and provided a detailed site archive (see below).

The most common type of field work in the microregion was the digging of test trenches and pits in order to test for the presence of pile dwellings. Staško Jesse opened a number of trenches in the vicinity of Maharski and Resnikov prekop (Jesse 1954). Tatjana Bregant, introduced a large-scale systematic testpit project between Parte and Kepje, and smaller ones around Resnikov (Bregant 1964b) and Maharski prekop (Bregant 1975). Parallel to archaeological fieldwork systematic coring programmes were conducted by palynologists (Śercelj 1975; 1981; Culiberg and Sercelj 1978) and soil scientists (Stritar 1975; Stritar and Lobnik 1985).

The radiocarbon and the dendrochronological data indicate that the south-eastern part of the Marshes was already settled in the tenth millennium BP. The earliest series from Breg and Babna Gorica (10200 cal BP to $7500 \mathrm{cal} \mathrm{BP}$ ) are followed by data from Maharski prekop (7500 cal BP) and Resnikov prekop (6700 cal BP) and series of dates from Maharski prekop and Parte (5800 cal BP to $4200 \mathrm{cal} \mathrm{BP}$ onwards) (see Tab. 1).

The chronological gap s between 7500 and 6500 and between 6500 and $5800 \mathrm{cal} \mathrm{BP}$ may be a consequence of the current state of research. Most of the radiocarbon dates were sampled in the 1970s and 1980s and dated by conventional radiometric methods. They were published either incompletely (missing lab codes) or even misleadingly, since conventional radiocarbon ages were not reported. This confusion is evident in the use of mutually exclusive dates for the same sample (Dimitrijevic 1979.179; Velušček 2006.Fig. 14). We have compiled all the available conventional radiocarbon dates in Table 1.

Over a hundred years of field activities in the microregion were concentrated in three distinctive clusters: around Resnikov prekop and Mostišč (the area around Maharski prekop), and between Kepje and Parte (Fig. 1).

The large number of discrete data-sets and the assumption that every test trench represents an isola-

1 The only remaining site plan is plan of excavations in 1875 (Vuga 1989).

2 In the vicinity of the Korošec's trench Anton Velušček (2006) excavated two test trenches of 12 and $9 \mathrm{~m}^{2}$ in 2005. 


\begin{tabular}{|c|c|c|c|c|}
\hline Labcode & $\begin{array}{c}\text { Conventional } \\
\text { radiocarbon age (BP) }\end{array}$ & Material & Context & Reference \\
\hline \multicolumn{5}{|c|}{ Breg pri Škofljici } \\
\hline$\overline{Z-1421}$ & $6630 \pm 150$ & charcoal & Test trench $84 / \mathrm{II}$, layer $3 \mathrm{a}$ & Srdoć et al. 1987.140 \\
\hline GrA-10015 & $9100 \pm 50$ & charcoal & Test trench 96/II, layer 17 & \\
\hline$\overline{\mathrm{GrA}-10012}$ & $8790 \pm 50$ & charcoal & Test trench 96/II, layer 11 & \\
\hline GrA-9860 & $8710 \pm 50$ & charcoal & Test trench $96 / \mathrm{II}$, layer 8 & \\
\hline GrA-10018 & $9180 \pm 50$ & charcoal & $\begin{array}{l}\text { Test trench 97, layer } 11 \\
\text { (stone platform) }\end{array}$ & \\
\hline \multicolumn{5}{|l|}{ Babna gorica } \\
\hline GrA-9857 & $6200 \pm 50$ & charcoal & Layer 17, (charcoal layer) & \\
\hline \multicolumn{5}{|c|}{ Resnikov prekop } \\
\hline Z-345 & $5718 \pm 23$ & wood & Excavations 1962 , pile 33 & Srdoć et al. 1987.354 \\
\hline $\mathrm{Hd}-24038$ & $5850 \pm 150$ & wood & Excavations 2005 , pile 5 & Čufar and Korenčič 2006.124 \\
\hline \multicolumn{5}{|c|}{ Maharski prekop } \\
\hline Z-278 & $4633 \pm 117$ & $\begin{array}{c}\text { wood } \\
\text { (Quercus?) }\end{array}$ & $\begin{array}{l}\text { Excavations } 1972, \\
\text { grid square } 12 \text { ?, pile } 40\end{array}$ & Srdoć et al. 1975.152 \\
\hline Z-305 & $4345 \pm 113$ & $\begin{array}{c}\text { wood } \\
\text { (Fraxinus) }\end{array}$ & $\begin{array}{l}\text { Excavations } 1973, \\
\text { grid square } 15, \text { pile } 1\end{array}$ & Srdoć et al. 1975.152 \\
\hline$\overline{Z-314}$ & $4964 \pm 99$ & wood & & Srdoć et al. 1975.152 \\
\hline Z-315 & $4701 \pm 104$ & $\begin{array}{c}\text { wood } \\
\text { (Sorbus) }\end{array}$ & $\begin{array}{l}\text { Excavations } 1972, \\
\text { grid square } 15, \text { pile } 4\end{array}$ & Srdoć et al. 1975.152 \\
\hline Z-351 & $5080 \pm 110$ & $\begin{array}{c}\text { wood } \\
\text { (Sorbus) }\end{array}$ & $\begin{array}{c}\text { Excavation s1974, } \\
\text { grid square } 42 \text {, pile } 156\end{array}$ & Srdoć et al. 1977.465-475 \\
\hline$\overline{Z-353}$ & $4330 \pm 120$ & wood & Excavations 1974 , test trench 4 & Srdoć et al. 1977.465-475 \\
\hline$A A-27182$ & $4680 \pm 55$ & Charcoal & $\begin{array}{l}\text { MP1 sediment exposure, } \\
\text { charchoal layer } 61-63 \mathrm{~cm}\end{array}$ & Gardner 1999.Tab. 5.1 \\
\hline Beta-219606 & $4740 \pm 40$ & bone (Ovis) & Grid square 42 & \\
\hline Beta-219607 & $4720 \pm 40$ & bone (Ovis) & Grid square 42 & \\
\hline Beta-219608 & $4710 \pm 40$ & bone & Grid square 42 & \\
\hline Beta-219609 & $6570 \pm 40$ & bone & Grid square 34 & \\
\hline Beta-219610 & $4750 \pm 50$ & bone & Grid square 34 & \\
\hline Beta-219611 & $4740 \pm 40$ & bone & Grid square 32 & \\
\hline \multicolumn{5}{|l|}{$\overline{\text { Parte }}$} \\
\hline Z-539 & $3920 \pm 100$ & wood & Excavations 1978 , pile 16 & Srdoć et al. 1977.133-134 \\
\hline Z-540 & $4010 \pm 100$ & wood & Excavations 1978 & Srdoć et al. 1977.133-134 \\
\hline$\overline{Z-646}$ & $4160 \pm 100$ & wood & Excavations 1979, pile 1 & Srdoć et al. 1977.412-413 \\
\hline$\overline{Z-647}$ & $4010 \pm 100$ & wood & Excavations 1979, pile 2 & Srdoć et al. 1977.412-413 \\
\hline$\overline{Z-716}$ & $4200 \pm 100$ & wood & Excavation 1979, pile 9 & Srdoć et al. 1977.412-413 \\
\hline$\overline{Z-982}$ & $4200 \pm 110$ & wood & Excavations 1982 , pile 325 & Srdoć et al. 1977-450 \\
\hline
\end{tabular}

Tab. 1. The conventional radiocarbon dates from Breg pri Škofljici, Babna gorica, Resnikov prekop, Maharski prekop and Parte.

ted pile dwelling have led many researchers into the reductionist illusion of many small, isolated sites populating the Neolithic and Eneolithic landscape.

However, if we assume that discrete sites which are spatially close and broadly contemporary are only visible fragments of single settlements, then only three larger settlement complexes can be identified in the micro-region: at Resnikov prekop, at Maharski prekop, and in the area between Parte and Kepje.
Even this image is incomplete, because of unsystematic fieldwork (see above) and the taphonomy of the landscape (see below). We may hypothesise single, large and dispersed settlement rather than three complexes, with the settlement foci shifting across the landscape in relation to changes in the landscape (Budja 1995; 1997; Mlekuž 1999; Budja and Mle$k u \check{z} 2001$ ) and the internal social dynamics of the groups inhabiting the floodplain. We should not forget that the floodplain was not utilised for settlement 
only, but also for agriculture. The landscape was therefore a shifting mosaic of hamlets, fields and pastures, structured by the pattern of the floodplain features.

\section{Landscape dynamics}

A peaceful paysage of pile-dwellings situated at the edge of the lake surrounded by mountains served as an interpretative model for interpreting Neolithic and Eneolithic settlement patterns and the palaeoenvironment on the Ljubljana marshes from the beginning of archaeological research there. Geomorphologists gave this image a definite structure in a model of simple and uniform hydroseral succession from lake to peat bog (Melik 1946; see also Šercelj 1966). Archaeologists, although faced with a more complex reality in the field, used this model of a stable landscape in archaeological interpretations, and have perpetuated the interpretative model formed in the mid-19th century. An interpretative vicious circle was formed when archaeological data was used to support environmental data and vice versa.

However, there are alternative scenarios which treat the Ljubljana Marshes as an inherently dynamic landscape (Šifrer 1983) and these serve as a point of departure for alternative interpretations of landscape change. As a consequence, a network of palaeochannels and their association with settlements was identified from aerial photographs, and processes that link palaeochannel migration with changes in the settlement pattern have been recognised (Budja 1995; 1997; Mlekuž 1999; Budja and Mlekuž 2001).

In order to further investigate the dynamics of the landscape, we conducted a LiDAR survey of the Iščica floodplain. An area $1300 \times 600 \mathrm{~m}$ around the Maharski prekop site was chosen for the LiDAR survey.

LiDAR (Light Detection and Ranging, or Laser Imaging Detection and Ranging, also known as ALSM, Airborne Laser Swath Mapping) is a technology that determines distances to an object or surface using laser pulses. 3 The results of LiDAR are very detailed, and precise digital surface models in which even the smallest changes in topography are discernible.

The LiDAR image of the area around Mahrski prekop shows a comprehensive image of the geomorpho- logy of the project area, particularly highlighting palaeochannels and earlier river courses, which can be seen as linear depressions in the landscape. The palaeochannels are not contemporaneous. Some channels are cut by younger ones, thus establishing a stratigraphic sequence. There are also differences in the shape, width, orientation and relative depth of the palaeochannel depressions. Consequently, at least four distinctive phases of fluvial activity can be discerned based on the relative stratigraphic positions of palaeochannels, their shapes and orientations (Fig. 2).

The first phase is characterised by thin straight channels oriented almost perpendicularly to the modern network. Their visibility in the landscape, the fact that they were not destroyed or covered by later activity, their form and orientation, show that they were formed under specific hydrological conditions. Straight channels are often the result of low discharges, small and suspended loads, low slopes, low channel width/depth ratios, and little or no bank erosion (Knighton 1998.65-70; Brown 1997.205-237).

The second phase was mostly destroyed by the activity of the third phase, and is marked by relatively wide sinuous channels which run in the same directions as recent streams. It might represent an early stage of the formation of the recent hydrological network. Transitions from straight to sinuous and meandering channels on constant slopes imply increasing discharge and higher width/depth ratios of the channels (Knighton 1998.65-70).

The third phase can be attributed mainly to lateral channel movement and the bank erosion of the modern Iščica and Želimeljščica streams before regulation works. These features are the most visible and cover the largest area. The most distinctive feature of the third phase channels are the sinuous forms of the larger streams and the meandering patterns of minor streams, and distinctive channel levees.

The fourth phase is a modern network, the result of flood-control and irrigation works, and consists of straight channels.

The change from straight to sinuous and meandering channels shows that there were significant changes in the hydrological regime of the streams drai-

\footnotetext{
3 The airborne mounted LiDAR sends out a scanning laser beam from the aircraft, which is reflected back to the sensor by the Earth's surface and the features on it. The time this takes is used to calculate the exact distance from the aircraft. The surface height is derived from knowing the aircraft's exact location and attitude, which are obtained from differential GPS and inertial navigation system measurements (Challis 2006).
} 
ning the Iščica floodplain. These can be attributed to increased discharge and, consequently, higher bank erosion and bed-load transport during the Holocene.

The palaeochannel sequence can be directly dated. The first phase palaeochannel was excavated on the Maharski prekop site and proved to be contemporary with the site. The dates of piles which are part of the structure associated with active channel (interpeted as 'revetment' by the excavator), fall between 5800 and $4800 \mathrm{cal} \mathrm{BP}$. The third phase palaeochannel eroded most of the stratigraphic integrity of the Resnikov prekop site. Radiocarbon dates from the on-site palinological sequence date the channel infill deposits to around $2300 \mathrm{cal} \mathrm{BP}$ and therefore give a terminus ante quem for the active channel (Andrič 2006).

A large portion of the area was disturbed by the fluvial activity which formed the landscape into a mosaic of isolated terraces separated by palaeochannels. Most of archaeological remains are located on these 'islands', or more precisely, on natural exposures (i.e. river and palaeochannel banks (Fig. 2). This has an important consequence for site recovery. Thus, sites without permanent structures are more likely to be completely destroyed or archaeologically invisible (buried) than sites with permanent structures (i.e. piles) which are more likely to be recovered. Therefore in the settlement pattern, sites with vertical piles exclusively are represented, given the lack of any other type of site.

However, even piles are not immune to bank erosion. The location of 'pile clusters' in the convex segments of the channels (where bank erosion is strongest and most recent) and their absence in the concave segments (Figs. 1, 2) demonstrate that bank erosion is a strong taphonomic agent which could not only erode original stratigraphic contexts, but also destroy more permanent features such as vertical piles.

The Iščica floodplain was a complex landscape, greatly shaped by fluvial activity. We argue that the hydrological regime changed during the middle Holocene, and that the earliest phase of palaeochannels was contemporaneous with the settlement at Mahar- ski prekop. Evidence of fluvial activity which predates those observed in the LiDAR images can be found near Babna gorica Hill, around $2 \mathrm{~km}$ northeast. In the $1.5 \mathrm{~m}$ deep section excavated on the edge of the floodplain several episodes of fluvial activity and flooding can be observed in stable isotope sequence (Fig. 3).

The carbon and nitrogen isotope record, as well as $\mathrm{C} / \mathrm{N}$ ratios in section ${ }^{4}$ shows some characteristic isotope transitions, indicating the presence of different types of organic material (Fig. 3). The upper part of the soil was fairly uniform, with average $\delta^{13} \mathrm{C}$ and $\delta 15 \mathrm{~N}$ values of $-28.9 \pm 0.2 \%$, and $4.2 \pm 0.4 \%$, respectively, while the $\mathrm{C} / \mathrm{N}$ ratio ranged between 34.7 and 47.3 , indicating the presence of vascular plants and corresponding to a terrestrial organogenic horizon (Meyers \& Teranes 2001; Jedrysek and Skrzypek 2005). The presence of dry land and buried wood fragments was observed at a depth of $55 \mathrm{~cm}$, where a layer of charcoal was found, dated to 7200 cal BP. At this depth the low $\delta{ }^{13} \mathrm{C}$ value as well as a slightly higher $\mathrm{C} / \mathrm{N}$ ratio, was determined. The layer between 61 and $66 \mathrm{~cm}$ had an isotopic signature similar to the upper part of the soil, indicating the presence of a terrestrial organogenic horizon. Larger changes were observed at a depth of $66 \mathrm{~cm}$ and lower. The isotopic composition of carbon changes to lower values, ranging between -29.3 and $-30.2 \%$, indicating the possible presence of aquatic plants and a wet layer. However, the $\mathrm{C} / \mathrm{N}$ ratios increased up to 114.6. The most plausible explanation for such a high $\mathrm{C} / \mathrm{N}$ ratio is the presence of a coarse sediment fraction and the possible presence of river activity. Similar changes in the isotopic composition and $\mathrm{C} / \mathrm{N}$ ratio and therefore the presence of river flow were observed at a depth of $55 \mathrm{~cm}$. The presence of river activity rather than a lake environment could be additionally supported if we compare the data with the sediment core taken at 'Na Mahu'. In this location lower $\delta 13 \mathrm{C}$ values were observed at different depths in parallel with low $\mathrm{C} / \mathrm{N}$ ratios approximately 7, indicating the presence of lacustrine algae ( $\mathrm{An}$ drič et al., submitted).

The sequence demonstrates intensive and complex fluvial and flood activity before $6700 \mathrm{cal} \mathrm{BP}$, with a

\footnotetext{
4 Organic carbon content (OC) and isotopic composition of organic carbon were determined after treatment with 1M HCl to remove carbonate material, while content of total nitrogen (TN) and isotopic composition of total nitrogen were determined without acidification. Weight percentages of OC and TN were analysed by a Carlo Erba elemental analyzer (model EA 1108). The precision of measurements was $\pm 3 \%$. The $\delta^{13} \mathrm{C}$ and $\delta^{15} \mathrm{~N}$ of $\mathrm{OC}$ and TN fractions were determined using a Europa 20 -20 continuous-flow stable isotope analyser with ANCA-SL preparation module. Isotopic ratios were expressed in $\delta$-notation in parts per mil (\%). For carbon, the standard is the V-PDB carbonate, while for nitrogen the standard is atmospheric (air) nitrogen. The overall analytical precision was $\pm 0.2 \%$ for $\delta 13 \mathrm{C}$ values and $\pm 0.3 \%$ of $\delta 15 \mathrm{~N}$ values.
} 
sequence of 'wet' and 'dry' episodes. In this case, even the presence of 'lacustrine' calcareous silt, traditionally an indicator of a stable lake, can be interpreted as a result of erosion and deposition by fluvial activity.

\section{Maharski prekop in context}

Large scale excavations of the Maharski prekop site by Tatjana Bregant from 1970 to 1977 are the largest excavation of a settlement in Ljubljana Marshes so far. However, test trenches excavated in the vicinity of the site, pile clusters in the Iščica river and in the modern Maharski ditch, and cores and sediment exposures from the immediate environs of the site, suggest that settlement extended much further across the floodplain than has been excavated. In 1953 Staško Jesse excavated a test trench in the immediate vicinity of the site, as well as 4 trenches towards the east. In three of them he found piles, stone features and pottery (Jesse 1954). Tatjana Bregant excavated six test trenches in the area around Maharski prekop and found archaeological material in three of them, all of them located on "slightly elevated terrain" (Bregant 1975.8-12), or natural exposures on the edges of phase 3 channels (as can be seen on the LiDAR map (see the discussion of taphonomy above). Around $100 \mathrm{~m}$ to the SE, in the River Iščica, two pile clusters were documented ( $\breve{C u f a r}$ et al. 1998). They are known as Spodnje mostišč 1 and 2 in the archaeological literature. Bregant made a series of boreholes northwest of the site, where she found pottery fragments, charcoal and wood fragments (Bregant 1975.9). Layers of charcoal are visible in the sediment exposure in the modern ditch, where vertical piles can be found in the bottom of the ditch (Gardner 1999.165-167). All these subsurface windows therefore provide only a fragmentary picture of the settlement around the Maharski prekop (Fig. 4).

All these subsurface windows are broadly contemporaneous and overlap with the duration of the settlement area excavated by Bregant. The radiocarbon and dendrochronological dates of Maharski prekop, Spodnje Mostišč 1 and 2, and test trench 4 are evidence of settlement in the area between 5800 and $4300 \mathrm{cal} \mathrm{BP}$.

In addition, available environmental data attest to land use and a human presence in the area. As demonstrated by Adam Gardner (1999), the floodplain around the Maharski prekop site was forested through the early occupation period, but the forest was progressively thinned towards the end of the settlement. In the MP1 palinological sequence (sediment exposure in the bank of the drainage ditch around $50 \mathrm{~m}$ from the excavated area) cereals are present at least from $6000 \mathrm{cal} \mathrm{BP}$. Around $5500 \mathrm{cal}$ BP a massive increase in charcoal deposition (visible as a thick charcoal layer) records firing events related to human activity in the vicinity of the exposure. This event also marks a sharp decline in arboreal pollen and an expansion of herbaceous taxa, including cereals. Around $5500 \mathrm{cal} \mathrm{BP}$, the area in the vicinity of the Maharski prekop was cleared and used for agricultural activities. The presence of cereal pollen (see also Šercelj 1975.121) clearly demonstrates the presence of fields in the vicinity of the site.

LiDAR imaging reveals a network of palaeochannels covering the area around Maharski prekop. One of the palaeochannels (dated to phase one, see above) was excavated on the Maharski prekop site, proving that it was contemporaneous with the site. Moreover, we have evidence of a human response to the bank erosion in the form of a series of piles at the edge of the channel, intepreted as a revetment that protected the site from bank erosion. LiDAR imaging reveals that there are even more palaeochannels in the vicinity of the site. However, taphonomy processes related to the bank erosion of the third phase palaeochannels destroyed most of the area south of the site and the southern part of the site itself.

These palaeochannels, presumably contemporary with the settlement, reveal a microtopography suitable for settlement, which although prone to seasonal flooding, offered an attractive resource for floodplain agriculture. Therefore, we can imagine Maharski prekop as a dispersed settlement with several settlement foci located on the channel levees and surrounded by fields. Some foci were settled for a very short time - less than 100 years in the case of Spodnje mostišče (Čufar et al. 1998.85-80) - but some (Maharski prekop) were occupied continuously for almost a millennium, or even two millennia, as recent radiocarbon data demonstrate (Tab. 1).

\section{The spatial organisation of the site}

Only large scale excavations offer an opportunity for better understanding the spatial structure of the sites. Thanks to the large area excavated by Tatjana Bregant, it is possible to assess the organisation of space within the Maharski prekop settlement. Bregant interprets it as a single phase 'pile-dwelling', with several raised platforms where small houses 
were located (Bregant 1975.17-30). Human activity was performed exclusively on the platforms, which had clay floors and stone features.

The archaeological record is, in her opinion, the result of destruction, disintegration, or the burning of platforms and the consequent inclusion of clay floors and stone features in the cultural layer. She hypothesised that the stratigraphic relations between clay house floors and stone features are the results of the different weights of features which sank to different depths after the collapse of the platform (Bregant 1975.14-17).

This interpretation is not realistic. First, the weight of the features built on the platforms would have been enormous and require extremely strong structures to support them. We calculated that the dolomite sandstone feature alone (see below), which she believes was originally deposited on the platform (Bregant 1975.14) would have weighed at least $18000 \mathrm{~kg}$. Ironically, it is located in an area with a low concentration of piles (there are only around 10 piles in the area covered by the feature). Second, no remains of platforms were found. Given the excellent preservation of organic material, one would assume that the remains of the platforms would be preserved (sealed in their original stratigraphic condition) under house floors and stone features, but this is not the case. Very few superstructural wooden elements were found, indicating that they were burnt or washed away, and there was nothing above them which would have sealed them in the sediment matrix. In the only case where horizontal piles were found in what was presumably their original position, they are located above the clay house floor and can be interpreted as part of a house superstructure. 5 Another very problematic point is the obvious stratigraphic superposition of clay floors (see below), which indicate that houses were periodically renewed.

Departing from contradictions and building upon Bregant's site documentation, we are able to offer an alternative interpretation of the site.

First, we have to consider the taphonomy of the site. This was obviously located at the active channel which runs to the east of the excavated area (see above, Figs. 1, 2, 4). A distinctive cut in the 'cultural layer' is visible in the sections, the result of the bank erosion of the stream. In the southern part of the ex- cavated area, further destruction can be observed in the lower density of piles and lack of a 'cultural layer'. This erosion can be identified on the LiDAR map as a third phase channel (Fig. 2). However, the central, western and northern parts of the site were not damaged by channel erosion.

One of them most obvious features on the site are vertical wooden piles preserved by water-logging (Fig. 5). There were 2332 vertical piles recorded on the site, which means that average vertical pile density is almost two piles per square meter. However, piles are obviously not scattered across the site at random. A linear arrangement of piles can be observed over most of the undisturbed part of the excavated area. Piles are organised in parallel rows, three at a time; they are about $8-10 \mathrm{~m}$ long and spaced $1.7-2.4 \mathrm{~m}$ apart. Mean pile diameter is $5.8 \mathrm{~cm}$ (standard deviation $3.8 \mathrm{~cm}, \mathrm{~N}=1743$ ), although piles with diameters up to $26 \mathrm{~cm}$ can be found. Larger diameter piles are often split ( $28 \%$ of all piles). Only three woods, oak (Quercus), ash (Fraxinus) and rowan (Sorbus) comprise more than of $90 \%$ of identified taxa (Šercelj 1973; 1975). Piles can be very long; some recovered piles were driven up to $3 \mathrm{~m}$ into the silt (Bregant 1974b.43).

Other distinctive features (Fig. 5) are two or three dense linear concentrations of piles running along the channel on the eastern side of the excavated area. Piles in these structures are generally of much smaller diameters than those in the central part of the excavated area (mean $3.2 \mathrm{~cm}$, standard deviation $1.4 \mathrm{~cm}, \mathrm{~N}=467$ ), and split piles are almost non-existent (5\%). The type of wood used for these is much more diverse than in the central part of the site (Šercelj 1973; 1975). Some piles from the easternmost row are not embedded in the 'cultural layer' and are inclined towards the channel, which obviously eroded the 'cultural layer'. The excavator interpreted these structures as a revetment (Bregant 1975.17-20, Fig. 1), which seems reasonable, considering the evidence of the palaeochannel (see above).

Common features on the site are concentrations of stones (Bregant 1974a.12; 1974b.41; 1975.14-15) (Fig. 6). Stones form distinctive clusters or features that are commonly found at the peripheral ends of pile rows; stones are sometimes distributed along lateral rows of piles and are often associated with charcoal. Querns are often components of these features.

5 A similar situation can be found at Parte (Harej 1981.Priloga 1). 
Another notable feature are clay surfaces, often burned (Bregant 1974b.12; 1975.14-15) (Fig. 6). They can be up to $20 \mathrm{~cm}$ thick, and cover large areas between rows of piles. Charcoal, wood debris, parts of superstructure, pottery and bones often rest directly upon those surfaces. The direct stratigraphic superposition of stone features and querns on the clay floors can be observed in some cases, indicating that they were used and deposited on the surfaces of clay floors. Therefore, clay floors can be interpreted as occupational surfaces both inside and outside houses, trampled and preserved by fire.

Charcoal lenses are often embedded in the "cultural layer", sometimes in stratigraphic relation to the clay occupational surfaces. Their presence indicates burning events.

If all this data is integrated into a wider picture, it is difficult to interpret it as the remains of pile-dwelling. We believe that the archaeological record reveals the remains of a group of houses with sizes of around 8-10 $\times 3.5-4.5 \mathrm{~m}$ arranged parallel to each other. ${ }^{6}$ Each house is made of three rows of structural timbers, with a central row of centre-posts supporting a roof ridge pole; the lateral rows are wall posts. The floors were plastered with clay, and the stone features are probably the remains of thermal structures in the front/back of the house, or possibly paved surfaces. Houses were oriented with the longer side parallel to the channel. However, there is at least one house which is oriented perpendicularly to the others (Fig. 7).

We have already pointed out that Maharski prekop has been interpreted as single phase, short occupation site (Bregant 1974a; 1974b; 1975; Velušček 2001.77). No attempt was made to associate piles with the stratigraphic contexts. However, we suggest that piles can be - at least tentatively - phased and related to the features. The layers of charcoal associated with house floors indicate that most of the houses were destroyed by fire. When fire razed the superstructures, only parts of the posts below the occupational surface survived. Thus the heights of the piles indicate the levels of occupational floors at the time when the houses were destroyed. Since the original surface of the settlement is irregular, we can not directly compare the heights of the remaining piles, but we can relate them to the surface of the cultural layer, interpolated from the published sections. On this basis we can establish a provisional phasing of the piles. Piles under the surface of the cultural layer are therefore older than piles extending above the cultural layer. Thus two phases of the settlement, older and younger, can be identified. 7 We can see that piles from both phases are not distributed randomly (Fig. 8); instead, piles from the same phase tend to be clustered in groups that we have identified as houses (see above, Fig. 7). As a consequence, these support our interpretation of pile-rows as the remains of houses, and enable us to phase the houses themselves (Fig. 8).

Phasing of the occupation of the settlement can be refined through analysis of the stratigraphic sequence (Figs. 9, 10, 11, 12).

The excavator identified a very simple stratigraphic sequence, which starts with calcareous lacustrine silt, a 'pre-settlement' gyttja (organic detritus mud) layer, a cultural layer which in composition is very similar to the pre-settlement layer, a layer of gyttja and a layer of yellowish clay, followed by a 'sub-humus' and 'humus' topsoil layer (Bregant 1974a.8-10; $1974 b$. 39-42; 1975.12-17). This sequence directly reflects Melik's view of a gradual transformation from lake to swamp and peat-bog (Melik 1940), placing settlement in a period of the progressive drying up of the lake and the formation of the swamp (Bregant $1974 b .13,22 ; 1975.12-17,48)$. However, as we have seen in the case of Babna gorica (see above), the situation is not that simple.

The same can be said of the 'cultural layer'. The excavator identified a single 'cultural layer', which she believes indicates only one phase of occupation. However, the 'cultural layer' is not uniform. Instead, she documented several changes in composition (sometimes even referred to as layers) and a number of features which are part of the 'cultural layer'. Stratigraphic relations between these features can be recognised, and the stratigraphic sequence established.

In the northwest part of the settlement several phases of occupation can be detected (Fig 10). The earliest phase is evidenced by the occupation debris directly on the pre-settlement surface and is covered

\footnotetext{
6 This interpretation is supported by the dendrochronological analysis of building phases on the Parte-Iščica pile cluster, where several phases of houses (albeit of smaller dimensions) were detected (Velušček et al. 2000.88-96).

7 Interestingly, Deschmann in two of his notes describes the overlapping clusters of vertical piles and the sequence of layers and 'cultural' deposits of 2,7m thickness in between (Smole 1983.149, 155).
} 
by an 'intense black' layer. 8 Upon this feature lie patches of fine sand and fragments of burnt clay floor, indicating a flood event which eroded the occupation surface. The 'cultural layer' above indicates stable occupation. However, on top of the cultural layer were new clay floors associated with thin layers of charcoal. Thus we have evidence of several phases of occupation interrupted by fires and floods.

A similar stratigraphic complexity can be observed in the central part of the settlement, where two distinctive strata separated by a thin lens of charcoal can be observed (Fig. 11). A cut was dug in the 'cultural layer' and filled with dolomite sandstone 'plates' mixed with charcoal. This feature covers a large area and can be traced on several sections. Its volume is estimated at approximately $15 \mathrm{~m}^{3}$. The material was obviously brought from elsewhere, probably from Grmez Hill on the edge of the Marshes. A clay floor was built directly on the surface of this feature (Bregant 1975.14-15).

The presence of clay floors has already been noted above. However, the relative heights of the clay floors within the cultural layer indicate that they were not contemporaneous. In some cases, direct stratigraphic superposition of house floors can be observed. Thus, in the southern part of the excavated area, we have evidence of the superposition of two clay floors separated by a thin layer of occupational debris (Fig. 12). This may indicate the periodic rebuilding of surfaces. The final phase of occupation can be detected in the series of clay floors built on top of the cultural layer which were covered with wood debris and charcoal, indicating that the site was abandoned after fire.

An important observation is that clay floors do not appear throughout the 'cultural layer'. Instead, they can be traced only in the upper parts of the "cultural layer'. No clay floors were found directly on the pre-settlement surface, where other features can be found (see above, Figs. 10, 11). This indicates that houses represent only later phases of the settlement and that earlier settlements may not have been associated with houses. We have shown that clay floors and piles can be associated as they are parts of the same structures (houses, see above). The radiocarbon data available (Tab. 1) are mostly for wooden piles and are therefore biased towards latter phases of the settlement. Most of the new radiocarbon dates for bones fall within this chronological framework. However, a radiocarbon datum for bone from grid square 34 obviously document earlier settlement of the area. The existence of earlier phase settlement was proposed on the basis of pottery scatters deposited on the pre-settlement surface (Budja 1995.170; 1997.82).

\section{Conclusions}

Earlier interpretations of the Ljubljana Marshes were based on the study of isolated fragments of data without reference to the wider context. This reductionist approach failed to acknowledge the complex dynamics of the Ljubljana Marshes landscape.

We have presented evidence to show that the Iršica floodplain was a complex landscape, greatly affected by fluvial activity. LiDAR images of the micro-region clearly demonstrate a pattern of stratified palaeochannels that structured the landscape. Evidence of similar fluvial activity which predates those observed in the LiDAR imaging can be found near on the edge of the floodplain, around $2 \mathrm{~km}$ north-east, where the stratigraphic and stable isotope sequence document several episodes of fluvial activity and flooding.

Dynamics are also visible in the settlement pattern, where, instead of many small isolated sites, we can speak of a large dispersed settlement shifting according to changes in the landscape and the social processes of the group inhabiting it.

We have challenged the idea that 'pile dwellings' were short-term, single phase settlements. Instead, the analysis of Maharski prekop stratigraphic evidence and new radiocarbon data shows that it was a multi-phase settlement, with an early phase occupation without permanent wooden structures, and latter phases of settlement with group of houses located on dry ground beside the active stream.

\section{ACKNOWLEDGEMENTS}

This research was supported by the Slovenian Research Agency, project J6-6013-0581.

8 The scatters of Resnikov prekop pottery type were found in this stratigraphical position (directly on the pre-settlement surface) on the site (Bregant 1974a.52; 1975.41; Velušček 2001.Sl. 29). 


\section{REFERENCES}

ANDRIČ M. 2006. Does pollen record in archaeological 'cultural layer' tell us what vegetation was growing around the settlement? Case study: 'Resnikov prekop'. In A. Velušček (ed.), Resnikov prekop. Opera Instituti archaeologici Sloveniae 10. ZRC Publishing, Ljubljana: 103-113.

ANDRIČ M., KROFLIČ B., TOMAN M. J., OGRINC N., DOLENEC T., DOBNIKAR M. and ČERMELJ B., submitted. Changes of Late Quaternary vegetation and hydrology on Ljubljansko barje (Slovenia). Journal of Quaternary Science.

BREGANT T. 1964a. Poročilo o raziskovanju kolišča in gradbenih ostalin ob Resnikovem prekopu pri Igu. Poročilo o raziskovanju neolita in eneolita $v$ Sloveniji 1: 724.

1964b. Sondažna izkopavanja v okolici Iga na Ljubljanskem barju. Arheološki vestnik 15-16: 179-209.

1974a. Kolišče ob Maharskem prekopu pri Igu - raziskovanja leta 1972. Poročilo o raziskovanju neolita in eneolita v Sloveniji 3: 39-67.

1974b. Kolišče ob Maharskem prekopu pri Igu - raziskovanja leta 1970. Poročilo o raziskovanju neolita in eneolita v Sloveniji 3: 7-35.

1975. Kolišče ob Maharskem prekopu pri Igu - raziskovanja 1973. in 1974. leta. Poročilo o raziskovanju neolita in eneolita $v$ Sloveniji 4: 7-107.

BROWN A. G. 1997. Alluvial geoarchaeology. Cambridge University Press, Cambridge. (Cambridge Manuals in Archaeology).

BUDJA M and MLEKUŽ D. 2001. GIS support in reconstructing Neolithic flood-plain dynamics: The Ljubljana Moor case. In B. Slapšak (ed.), On the good use of geographic information systems in archaeological landscape studies. EUR. COST Action G2. European Communities, Luxembourg: 117-126.

BUDJA M. 1995. Spreminjanje naravne in kulturne krajine v neolitiku in eneolitiku na Ljubljanskem barju I. Poročilo o raziskovanju paleolitika, neolitika in eneolitika v Sloveniji 23: 163-181.

1997. Landscape changes in the Neolithic and copper ages in Slovenia: case study: the Ljubljansko Barje region. In J. Chapman and P. Dolukhanov (eds.), Landscapes in Flux: Central and Eastern Europe in antiquity. Colloquia Pontica 3. Oxbow books, Oxford: 7788.

CHALLIS K. 2006. Airborne laser altimetry in alluviated landscapes. Archaeological Prospection 13(2): 103-127.
CULIBERG M. and ŠERCELJ A. 1978. Ksilotomske in palinološke analize rastlinskih ostankov s kolišča na Partih pri Igu - izkopavanja leta 1977. Poročilo o raziskovanju paleolita, neolita in eneolita v Sloveniji 6: 95-107.

ČUFAR K., LEVANIČ T. and VELUŠČEK A. 1997. Dendrokronološke raziskave na kolišču Založnica in Parte. $A r$ heološki vestnik 48: 15-26.

1998. Dendrokronološke raziskave na koliščih Spodnje mostišče 1 in 2 ter Hočevarica. Arheološki vestnik 49: 75-92.

ČUFAR K. and KORENČIČ T. 2006. Investigation of wood from resnikov prekop and radiocarbon dating. In A. Velušček (ed.), Resnikov prekop. Opera Instituti Archaeologici Slovenia 10. ZRC Publishing, Ljubljana: 123-127.

DIMITRIJEVIĆ S. 1979. Lasinjska kultura. In Praistorija jugoslovenskih zemalja 3: eneolitsko doba. Akademija nauka i umjetnosti Bosne i Hercegovine, Sarajevo: 137181.

GARDNER A. 1999. The impact of Neolithic agriculture on the environment of south-east Europe. PhD Thesis, University of Cambridge, Cambridge.

HAREJ Z. 1978. Kolišče v Partih pri Igu na Ljubljanskem barju. Poročilo o raziskovanju paleolita, neolita in eneolita 6: 61-94.

1981. Kolišče v Partih pri Igu na Ljubljanskem barju. Poročilo o raziskovanju paleolita, neolita in eneolita v Sloveniji 9-10: 31-101.

1987. Kolišče v Partih pri Igu na Ljubljanskem barju raziskovanja leta 1981. Poročilo o raziskovanju paleolita, neolita in eneolita $v$ Sloveniji 15: 141-194.

JEDRYSEK M. O., SKRZYPEK G. 2005. Hydrogen, carbon and sulphur isotope ratios in peat: the role of diagenesis and water regimes in reconstruction of past climates. $E n$ vironmental Chemistry Letter 2Q: 179-183.

JESSE S. 1954. Poročilo o sondiranju v okolici Iga pri Ljubljani. Arheološki vestnik 5: 95-111.

KNIGHTON D. 1998. Fluvial forms and processes. Arnold, London.

KOROŠEC J. 1964. Kulturne ostaline na kolišču ob Resnikovem prekopu odkrite v 1962. Poročilo o raziskovanju neolita in eneolita $v$ Sloveniji 1: 25-64.

MEYERS P. A. 1997. Preservation of elemental and isotopic source identification of sedimentary organic matter. Chemical Geology 114: 289-302. 
MEYERS P. A. and TERANES J. L. 2001. Sediment organic matter. In W. M. Last and J. P. Smol (eds.), Tracking the Environmental Change Using Lake Sediments, Volume 2: Physical and Geochemical Methods. Kluwer Academic Publishers, Dordrecht, The Netherlands: 239-269.

MELIK A. 1946. Ljubljansko koliščarsko jezero in dediščina po njem. SAZU, Ljubljana. (Dela SAZU 5, prvi razred).

MLEKUŽ D. 1999. Landscape dynamics on the Ljubljana Moor. In M Budja (ed.), $6^{\text {th }}$ Neolithic Studies. Documenta Praehistorica 26: 185-200.

PARZINGER H. 1984. Die Stellung der Uferransiedlungen bei Ljubljana im aneolithischen und fruhbronzezeitlichen Kultursystem der mittleren Donaulander. Arheološki vestnik 35: 13-75.

1993. Studien zur Chronologie und Kulturgeschichte der Jungstein-, Kupfer- und Frühbronzezeit zwischen Karpaten und Mittlerem Taurus. Römisch-Germanische Forschungen 52, Frankfurt am Main.

SMOLE M. 1983. Dežmanovi zapisi o odkrivanju mostišč na Ljubljanskem barju. Poročilo o raziskovanju paleolita, neolita in eneolita 11: 143-170.

SRDOĆ D., SLIEPČEVIĆ A. and PLANINC J. 1975. Rudjer Bošković institute radiocarbon measurements III. Radiocarbon 17(1): 149-155.

SRDOĆ D., SLIEPČEVIĆ A., OBELIĆ B. and HORVATINČIĆ N. 1977. Rudjer Bošković institute radiocarbon measurements IV. Radiocarbon 19(3): 465-475.

1981. Rudjer Bošković institute radiocarbon measurements V. Radiocarbon 21(1): 131-137.

SRDOĆ D., OBELIĆ B., HORVATINČIĆ N. and KRAJCAR I. 1984. Rudjer Bošković institute radiocarbon measurements VIII. Radiocarbon 26(3): 449-460.

SRDOĆ D., OBELIĆ B., SLIEPČEVIĆ A., KRAJCAR BRONIĆ I. and HORVATINČIĆ N. 1987. Rudjer Bošković institute radiocarbon measurements X. Radiocarbon 29(1): 135147.

STRITAR A. 1975. Pedološke raziskave kolišča ob Maharskem prekopu pri igu - 1973. leta. Poročilo o raziskova- nju paleolita, neolita in eneolita v Sloveniji 4: 142144.

STRITAR A. and LOBNIK F. 1985. Pedološke raziskave kolišča Parte pri Igu. Poročilo o raziskovanju paleolita, neolita in eneolita v Sloveniji 13: 67-73.

ŠERCELJ A. 1973. Poročilo o ksilotonskih raziskavah kolišča ob Maharskem prekopu - raziskavnja leta 1972. Poročilo o raziskovanju neolita in eneolita $v$ Sloveniji 3: 69-70.

1966. Pelodne analize pleistocenskih in holocenskih sedimentov Ljubljanksega barja. Razprave $S A Z U$ : 431-427.

1975. Analize makroskopskih in mikroskopskih rastlinskih ostankov s kolišča ob Maharskemu prekopu, izkopavanja 1973. in 1974. leta. Poročilo o raziskovanju paleolita, neolita in eneolita v Sloveniji 4: 115-122.

1981. Pomen botaničnih koliščih Ljubljanskega barja. Poročilo o raziskovanju paleolita, neolita in eneolita v Sloveniji 9-10: 101-106.

ŠIFRER M. 1983. Nova dognanja o geomorfološkem razvoju Ljubljanskega barja. Geografski zbornik 23(2): 945 .

VELUŠČEK A. 2006. Resnikov prekop - Sample Trencing, Archaeological Finds, Cultural and Chronological Classification. In A. Velušček (ed.), Resnikov prekop. Opera Instituti Archaeologici Slovenia 10. ZRC Publishing, Ljubljana: 54-86.

2001. Srednja bakrena doba v osredni Sloveniji. $\mathrm{PhD}$ Thesis, University of Ljubljana, Ljubljana. Available in the Library of the Department of Archaeology.

VELUŠČEK A. and ČUFAR K. 2001. Dendrokronološke raziskave kolišč na Ljubljanskem barju - stanje 2001. Arheološki vestnik 49: 59-67.

VELUŠČEK A., ČUFAR K. and LEVANIČ T. 2000. Parte-Iščica, arheološke in dendrokronološke raziskave. Arheološki vestnik 51: 83-107.

VUGA D. 1989. Peruzzijev načrt kolišča ob Ižanski cesti iz leta 1875. Poročilo o raziskovanju paleolita, neolita in eneolita 17: 109-113. 


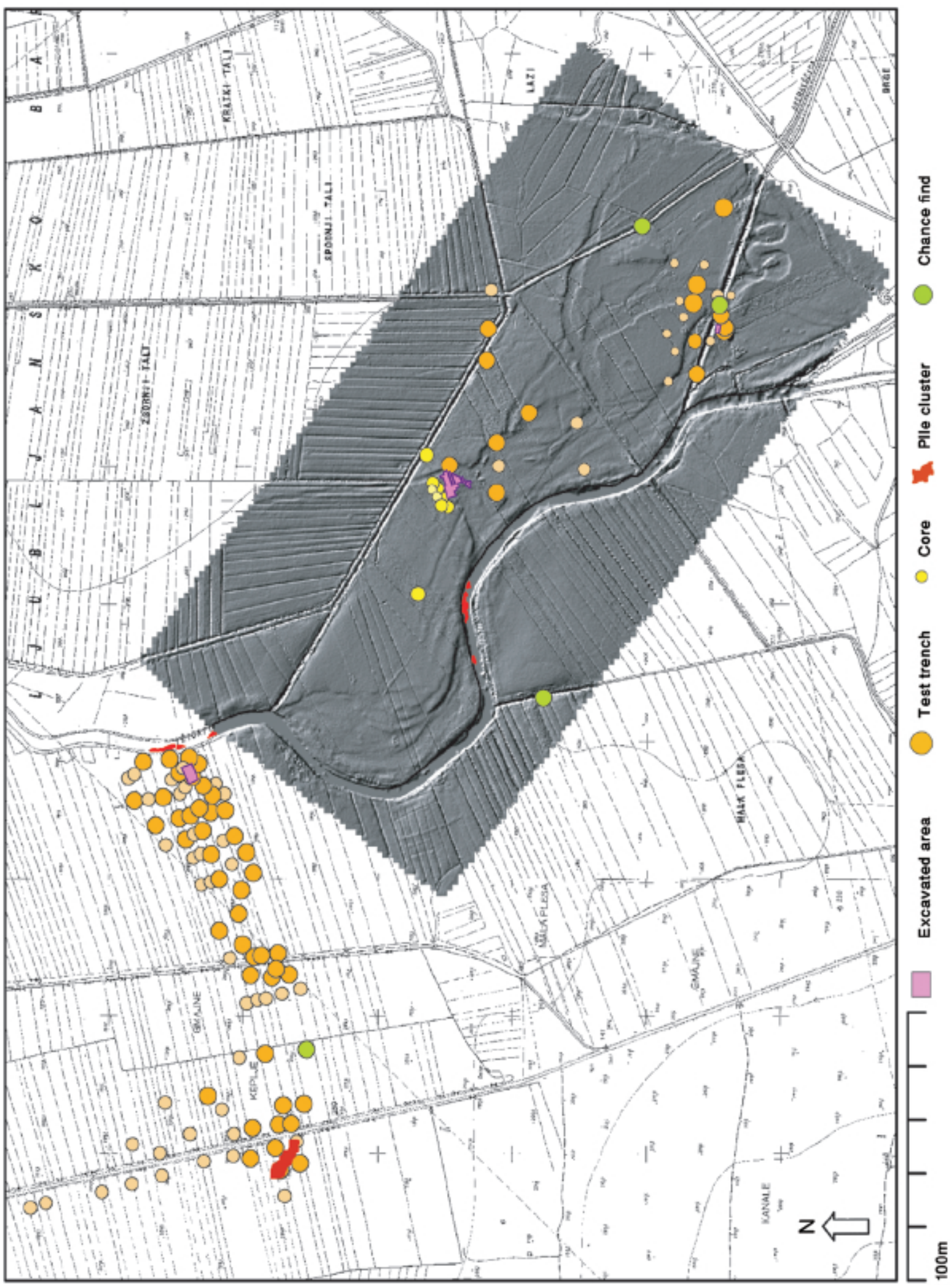

Fig. 1. Study area with map of archaeological excavations and test-trenches superimposed over LiDAR shaded map. Note the clustering of archaeological fieldwork around Resnikov kanal, at Mostišče and between Kepje and Parte. 

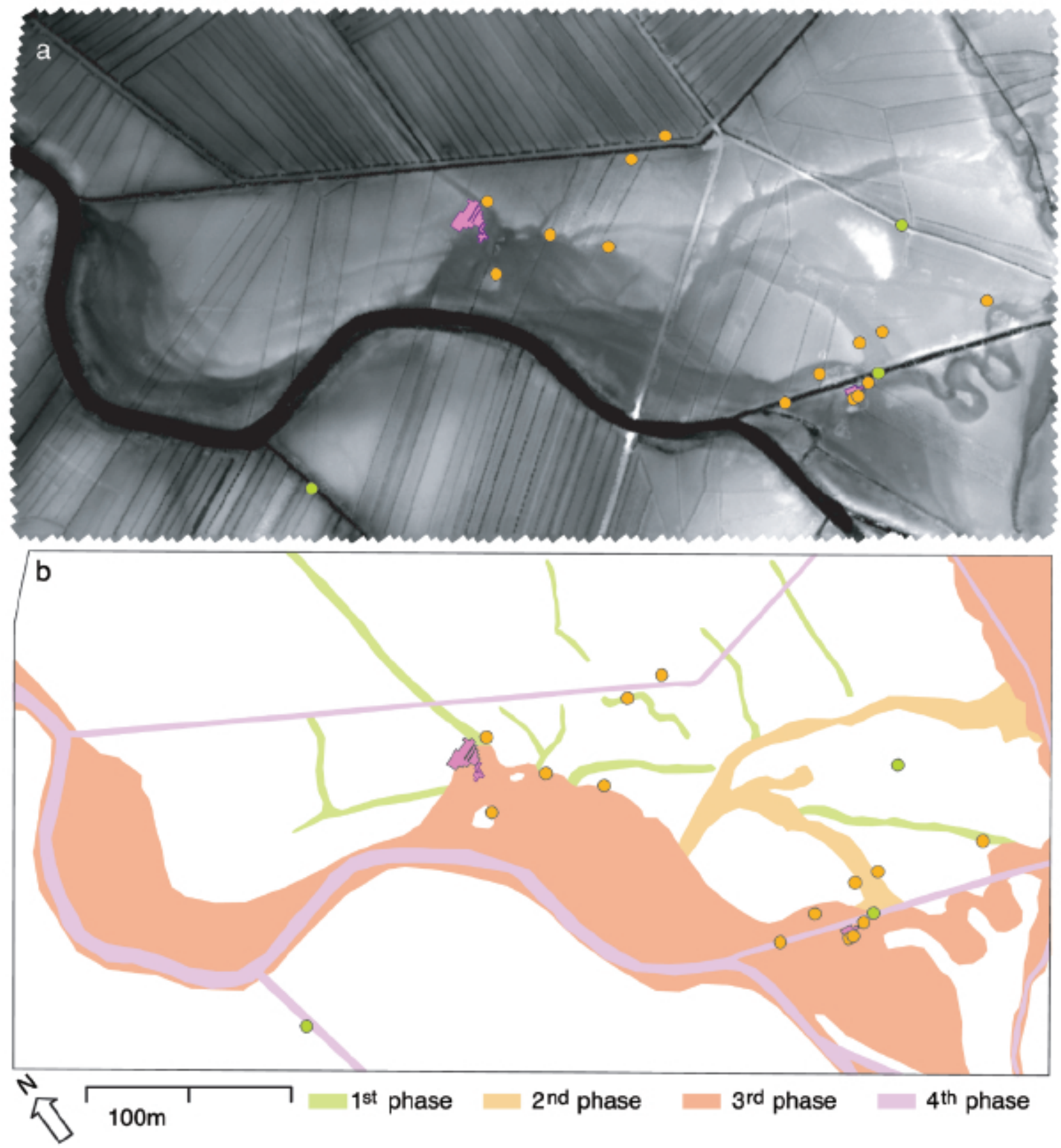

Fig. 2. LiDAR image (a) and its interpretation (b). At least three phases of superimposed palaochanels can be observed. The landscape is structured by an interlocking pattern of palaeochannels; most of the archaeological sites are located on the exposed edges of the undisturbed land. 


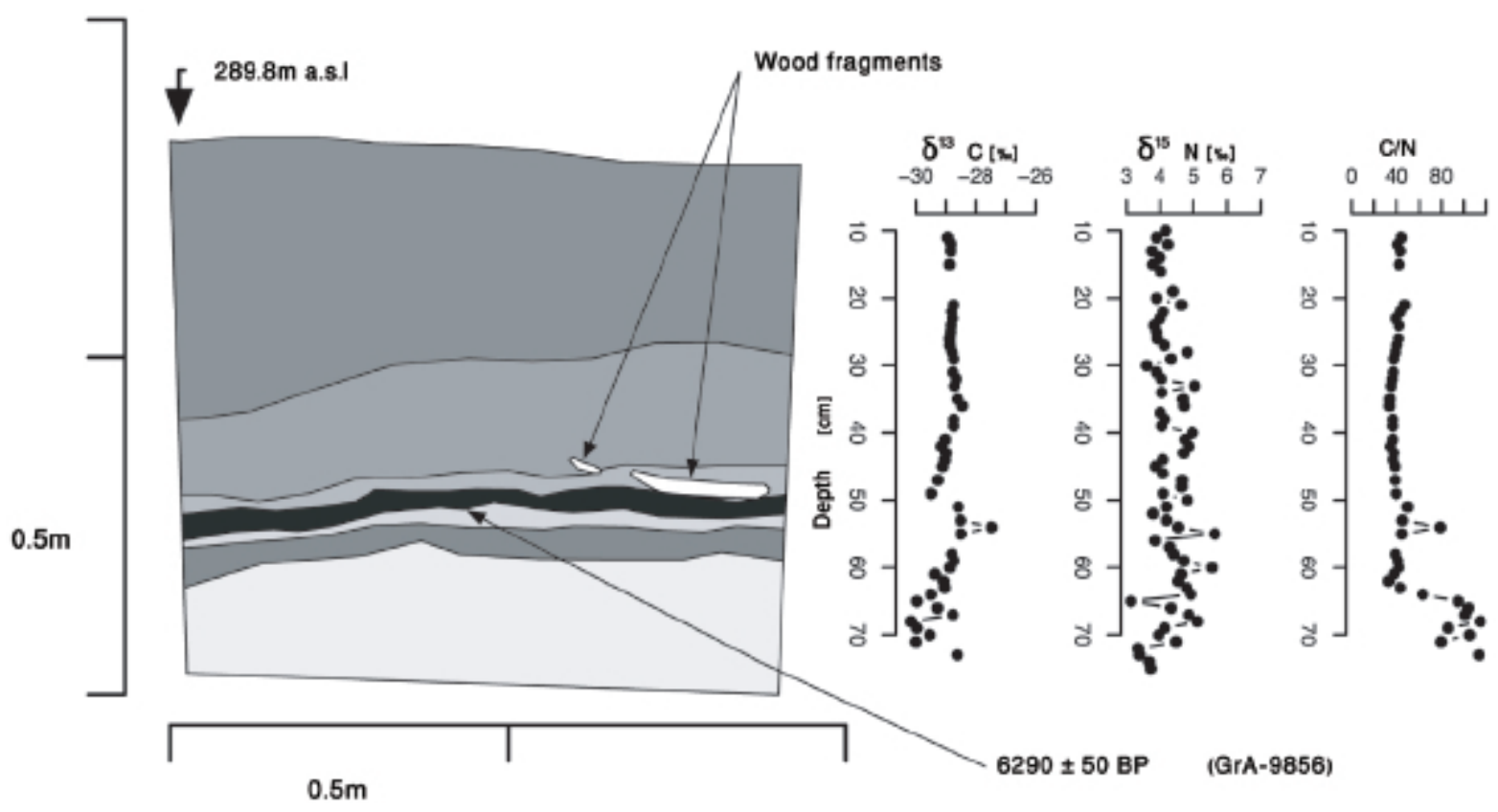

Fig. 3. Babna gorica test section with isotope date.

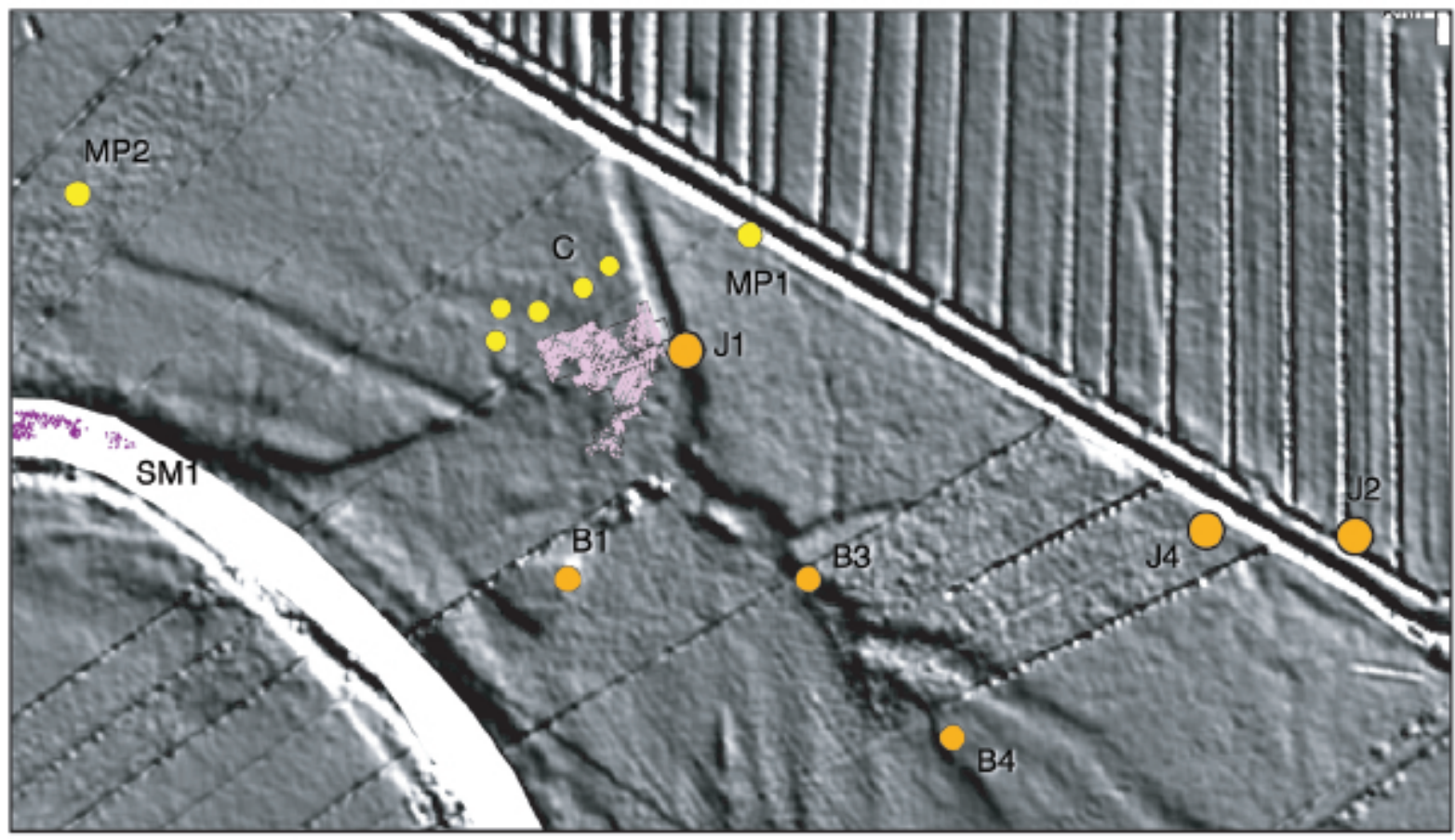

$50 \mathrm{~m}$

Fig. 4. Mostišče area on the LIDAR image. Maharski prekop is located just next to the palaeochannel. Note the network of palaeochannels in the area and destruction by the palaeochannel dated to the third phase. J1-J4 - Staško Jesse's test trenches (1954). B1-4 - test trenches by Tatjana Bregant (1975), C - Bregant's cores (1975), MP1-2 - pollen cores by Gardner (1999) and SM1 - Spodnje Mostišče pile cluster in modern Iščica. 


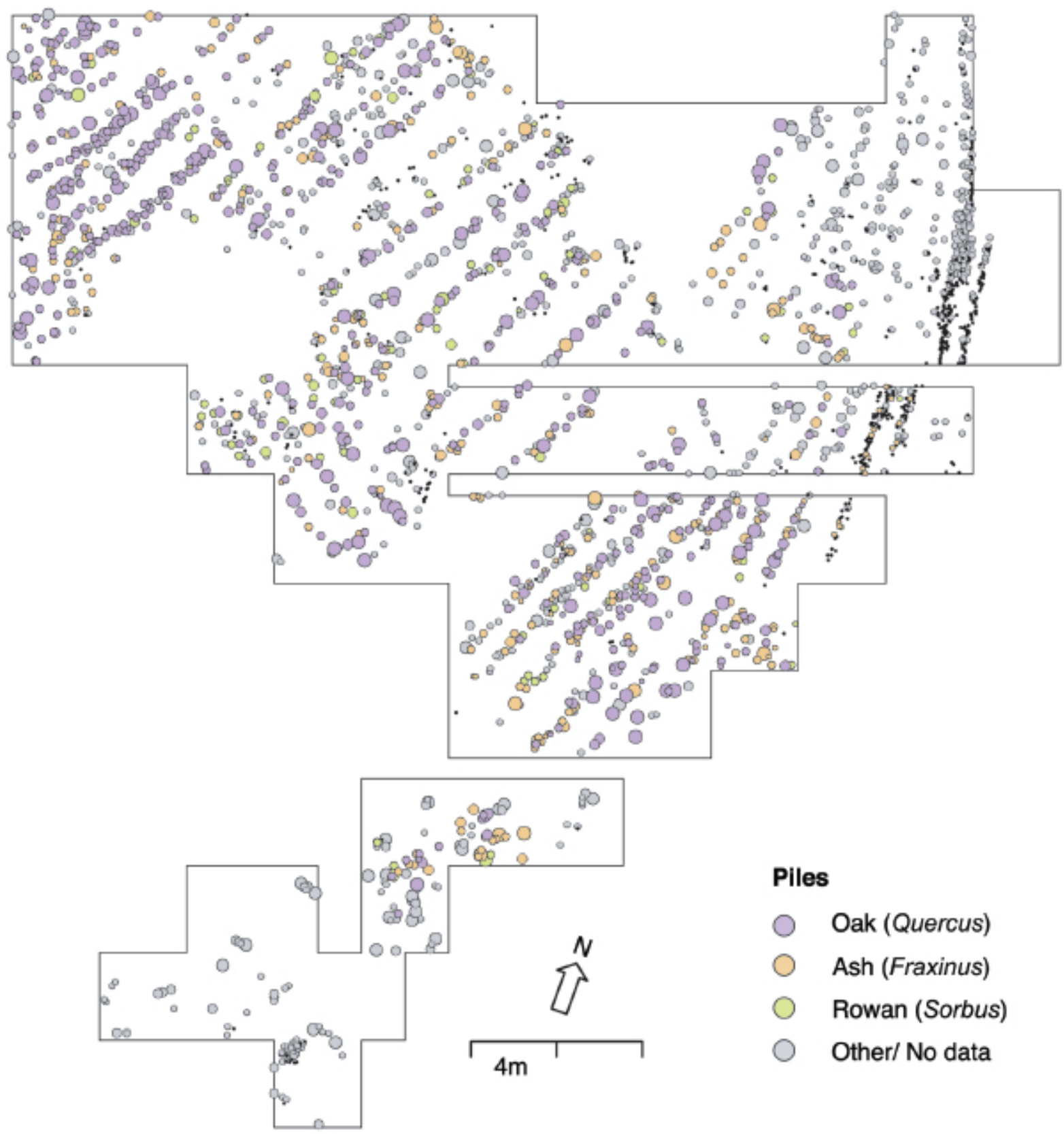

Fig. 5. Maharski prekop. Distribution of piles. Map is based on excavator's original documentation and published report (Bregant 1975.1-107, Priloga 2-4). 


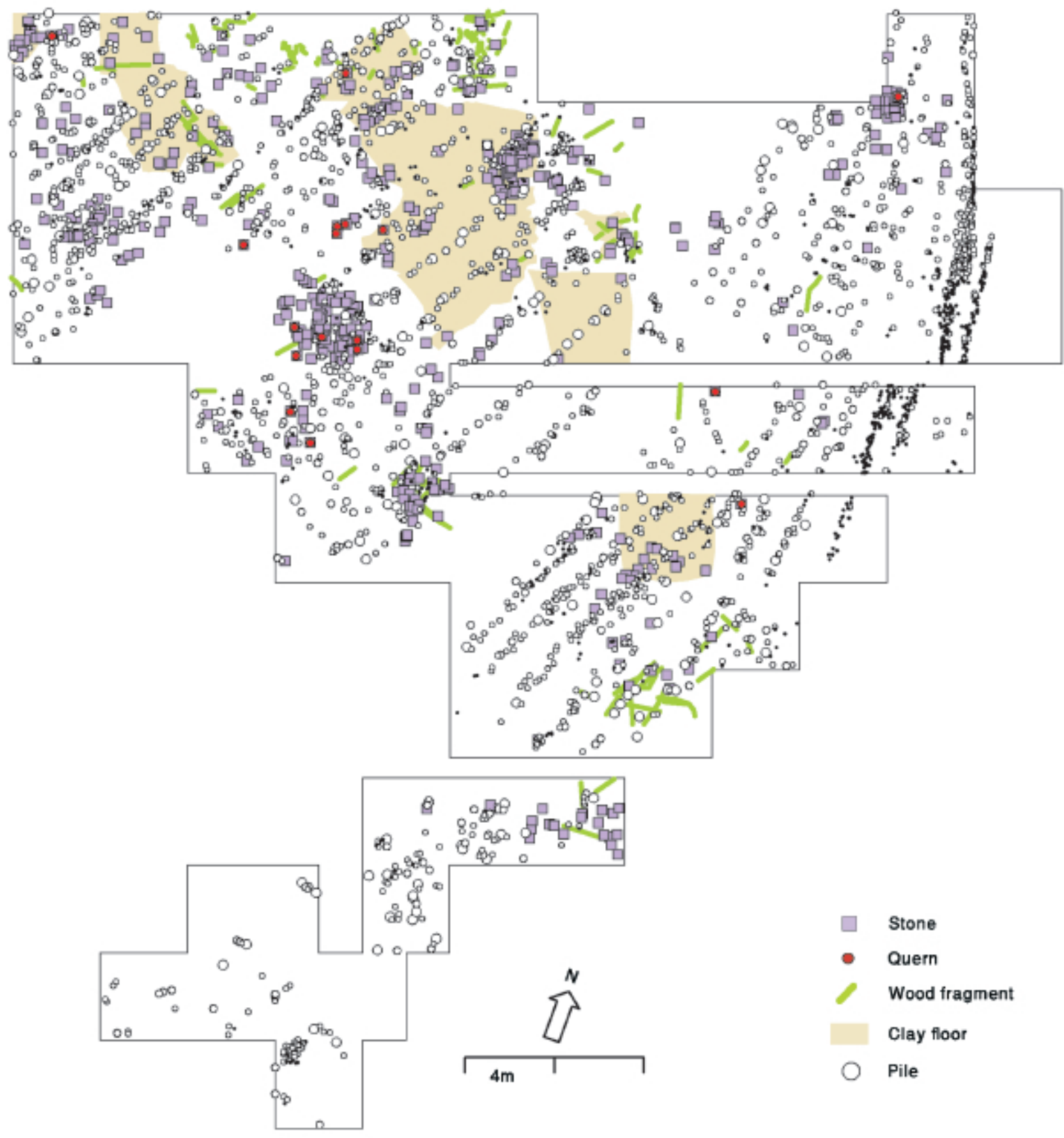

Fig. 6. Maharski prekop. Distribution of stone features, querns, clay floors and wood fragments. Map is based on excavator's original documentation and published report (Bregant 1975.1-107, Priloga 2-4). 


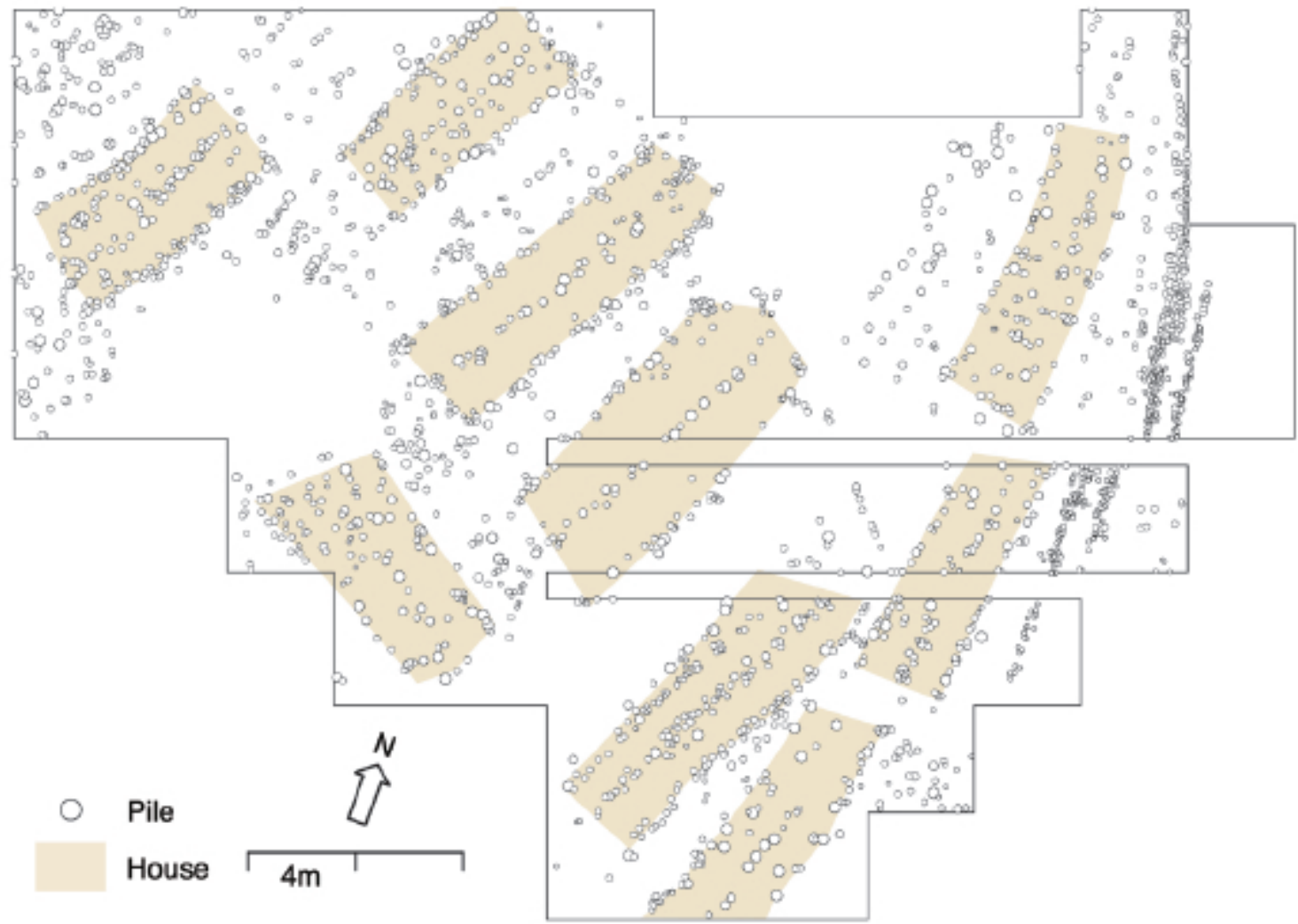

Fig. 7. Maharski prekop. Reconstructed house plans based on the distribution of piles and other features. Map is based on excavator's original documentation and published report (Bregant 1975.1-107, Priloga 2-4).

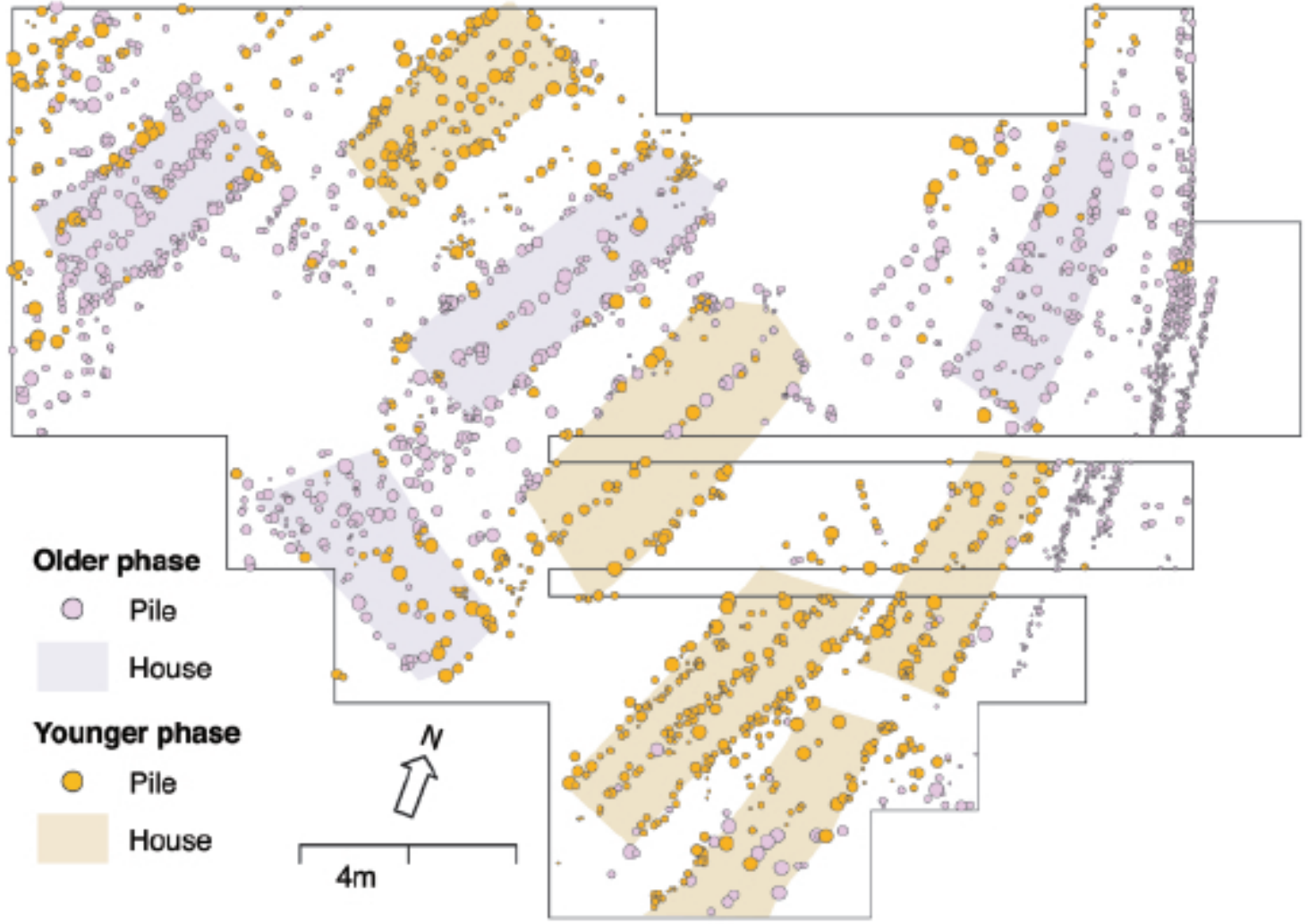

Fig. 8. Maharski prekop. Phasing of piles and houses based on the relative heights of the piles. Map is based on excavator's original documentation and published report (Bregant 1975.1-107, Priloga 2-4). 


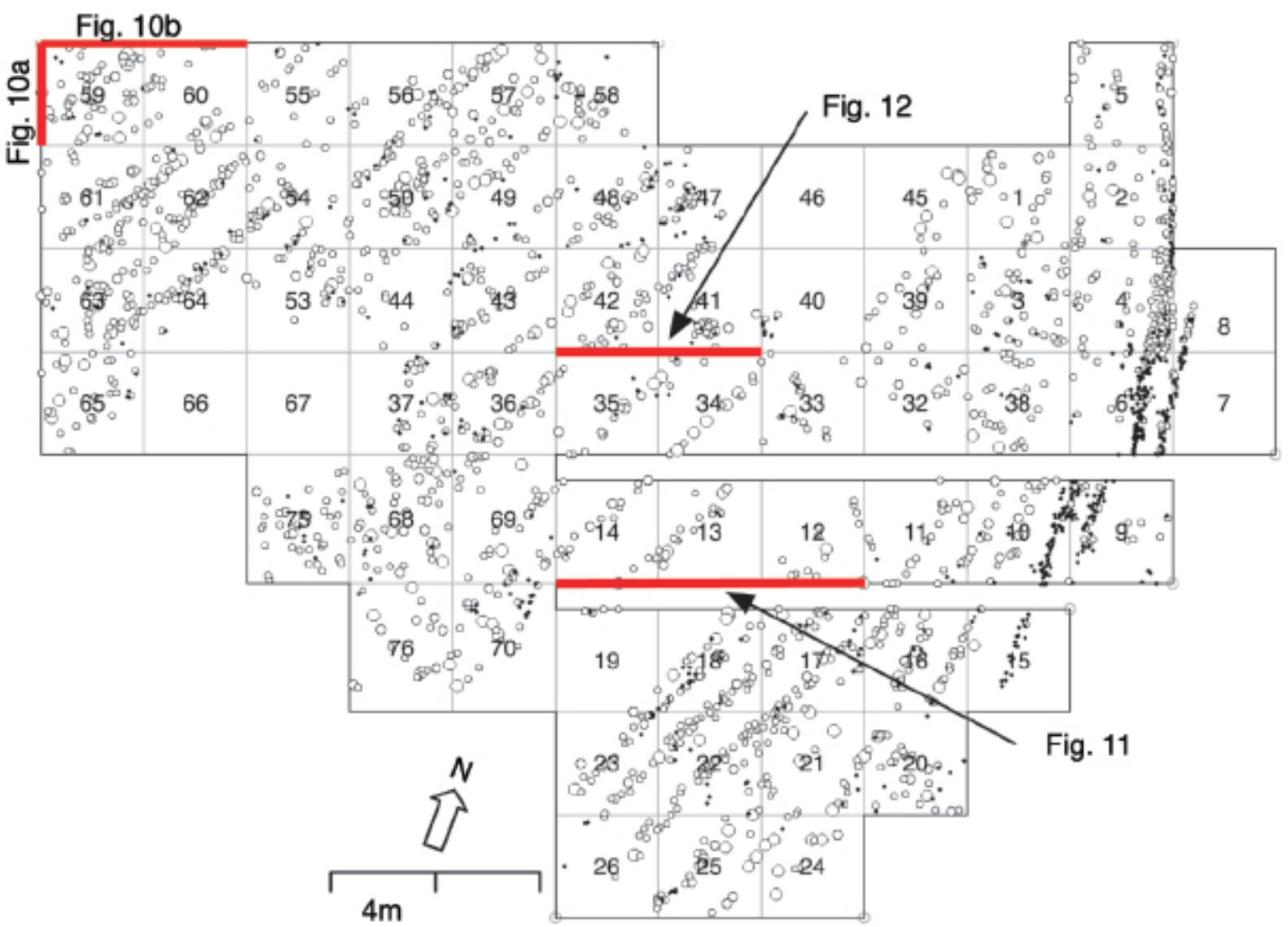

Fig. 9. Maharski prekop. Positionof the sections discussed in the text in the Bregant's grid system. Map is based on excavator's original documentation and published report (Bregant 1975.1-107, Priloga 2-4).

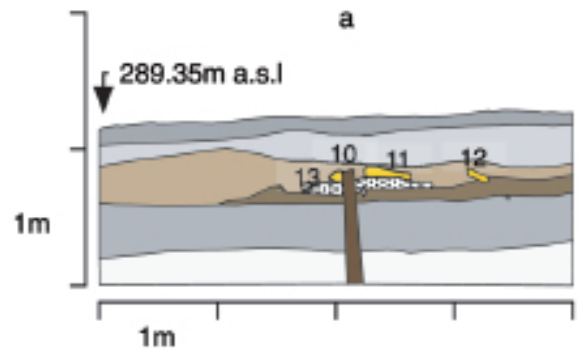

Fig. 10. Maharski prekop. Stratigraphic sequence in the north-western part of the settlement. 1 - topsoil; 2 - 'subhumus'; 3 - clay; 4 - burnt clay floor; 5, 6, 7, 8 - charcoal; 9 - cultural layer; 10, 11, 12 - burnt clay floor; 13 - fine sand; 14 - 'very dark cultural layer'; 15 - 'cultural layer'; 16 - pre-settlement 'gyttja'; 17 - calcareous silt. Figure is based on excavator's original documentation.

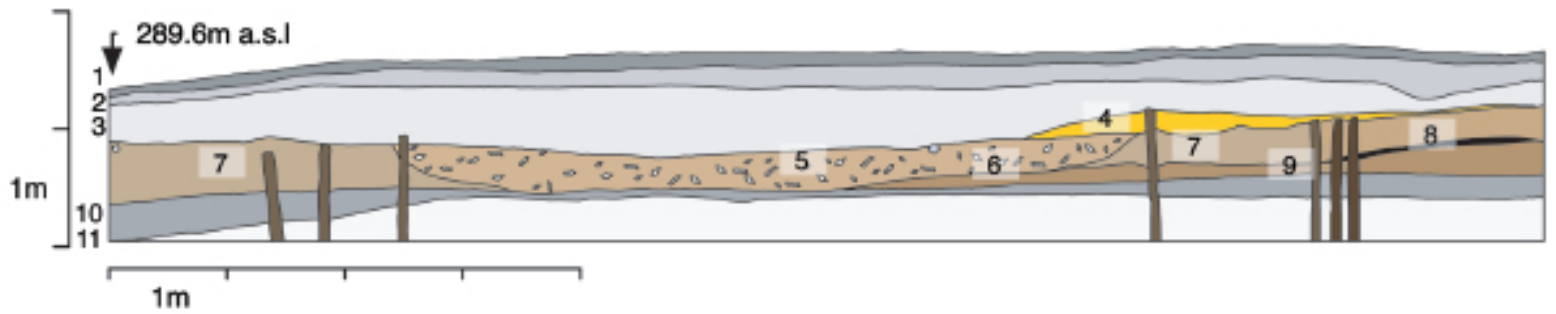

Fig. 11. Maharski prekop Cut, filled with dolomite sandstone plates, superimposed by the house floor in the central part of the excavated area. 1 - topsoil; 2 - 'subhumus'; 3 - clay; 4 - clay floor; 5 - dolomite sandstone 'plates' mixed with charcoal; 6 - cut; 7 - 'cultural layer'; 8 - charcoal; 9 - 'cultural layer'; 10 - pre-settlement 'gyttja'; 11 - calcareous silt. Figure is based on excavator's original documentation and published report (Bregant 1975.1-107, Priloga 2-4). 


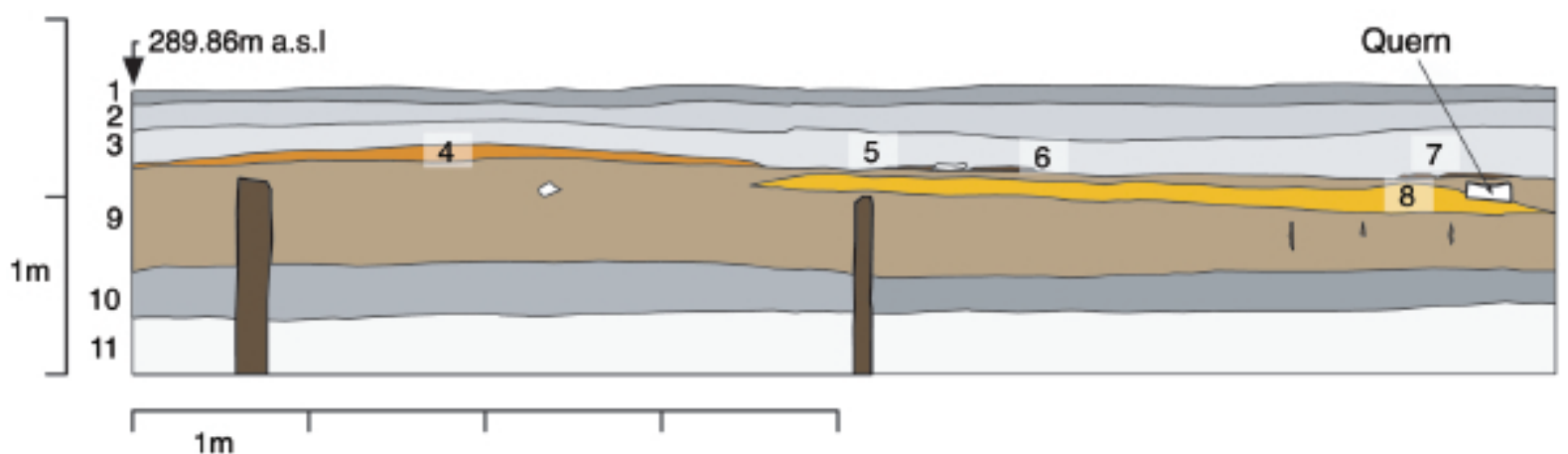

Fig. 12. Maharski prekop. Superposition of clay floors in the central part of the excavated area. 1 - topsoil; 2 - 'subhumus'; 3 - clay; 4 - burnt clay floor; 5, 6, 7 - charcoal; 8 - clay floor; 9 - 'cultural layer'; 10 pre-settlement 'gyttja'; 11 - calcareous silt. Figure is based on excavator's original documentation and published report (Bregant 1975.1-107, Priloga 2-4). 